\title{
PLANT SPECIES MAPPING AND DENSITY IN THE VILLAGE FOREST OF PENGLIPURAN, BANGLI, BALI, INDONESIA AND ITS USE IN LEARNING MEDIA
}

\author{
Nyoman Wijana1 ${ }^{1}$, , I Gusti Agung Nyoman Setiawan² \\ 1 University of Pendidikan Ganesha \\ 2 University of Pendidikan Ganesha
}

\begin{abstract}
Abstrak
The objectives of this research are to acknowledge the relative density index of plant species and the distribution of the plant species in the village forest of Penglipuran, Bangli, Bali, Indonesia, and (2) the utilization of his research results in instructional media. The population of this study is the whole area of Penglipuran village forest and all the plant species in it. The samples of this study are all plant species covered in 100 quadratics of size $10 \times 10 \mathrm{~m}$. The sampling technique used is systematic sampling. The data are analyzed descriptively. Population utilization of research result in instructional media use student of Department of Biology Education FMIPA Undiksha, Semester V class A, B, and C. The sample is student class V class A with number of student counted 25 people. The sampling technique is by using random sampling technique. The method of data collection is interview and observation. The data are analyzed descriptively. Result of this research are (1) The plant species distribution mapping result shows that the plant species have wide, medium, and narrow distribution. (2) From the 34 species which are included into 21 families, 10 of them have the highest relative density index. (3) The results of this research can be used as a media in learning Biology, especially in Plant Ecology.
\end{abstract}

\begin{tabular}{l} 
Keywords: \\
\hline Mapping, Density, \\
Penglipuran Village
\end{tabular}

\section{INTRODUCTION}

Indonesia is a country with high flora diversity, well-known for its natural resources. There are vast forest areas in various parts of Indonesia. Forests hold a very significant function as soil protector and water regulator. However, forest destruction is getting worse due to the uncontrolled logging activities, forest fires, timber utilization by the community and the extensive conversions of forest functions.

Forest destruction is one of factors that cause various species of plants extinct. In addition, the plant species extinction is also caused by natural disaster such as droughts, floods, or landslides, and also is caused by human activities such as illegal logging, rare plants trading, and intentionally forest fires.

One of forest destruction and ecosystem degradation impacts is the changing of plant density. Low plant density in vegetation can impact the climate and the soil factor itself. Impacts on the climate can cause disturbed geobiochemical cycles, air temperature, humidity, droughts, and others. The edafic factor influences the occurrence of landslides, soil fertility, soil microbiology, and the occurrence of dry land.

Many researchers have done studies on plant ecology fields, however the plant species names which construct the ecosystem studies are composed in a form of floristic only. Floristic list is a list of plant species names both in scientific name and local name. It is not completed with the distribution mapping of the plant species. Therefore the plant species those are still in the field hard to be detected, their distribution spots are unknown (Wijana, 2014).

Mapping of plants in their original nature is not much touched by the researchers. Most researches are oriented to basic research which contributes to the scientific development only. The suggested conservations are only normative. Furthermore, the stakeholders do not have any knowledge on the existence of the plants in the study area. It is not clear where the-to-be-preserved plants are. In addition, those plants description is not clearly described. The community does not know so well the plants in the study area with scientific names. They only know the plants by their local names, and the general 
description of the plants nature is less illustrated. Therefore it is important to do in-depth study on distribution mapping of the plant species in the village forest of Penglipuran, on the plant density in the forest ecosystem, and plant description for easy introduction.

Biology Learning especially the study of Plant Ecology requires learning media. This is due to the complexity of the forest environment conditions that become the object of learning. The results of this study can be used as a learning medium especially in the introduction of plant species, the implementation of field work, and learning in terms of data retrieval and analysis.

Therefore the objectives of this study is to acknowledge (1) the distribution mapping of plant species in the village forest of Penglipuran, Bangli, Bali, Indonesia and (2) The amount of plant species density index..

\section{RESEARCH METHOD}

This study is done in the whole forest area of Penglipuran Village, Subdistrict of Kubu, Regency of Bangli, Province of Bali, Indonesia. The location of this study can be seen on Picture 1.

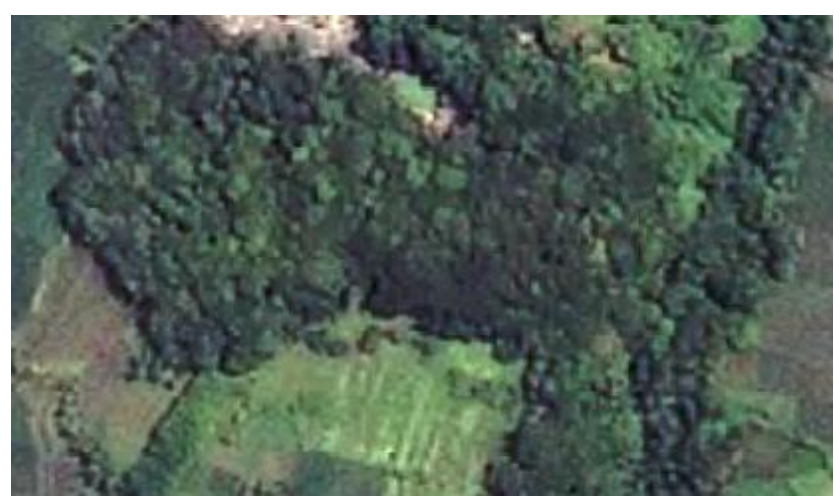

Picture 1. Penglipuran Village Forest Area.

(Source: Google Earth, 2017)

The population of this study covers the borders of Penglipuran Village and the entire plant species in the Penglipuran village forest of 1 hectare. The plant samples in this study are all plant species covered in 100 quadratics of size $10 \times 10 \mathrm{~m}$ with field research design. The quadratic installations are as shown on Picture 2.

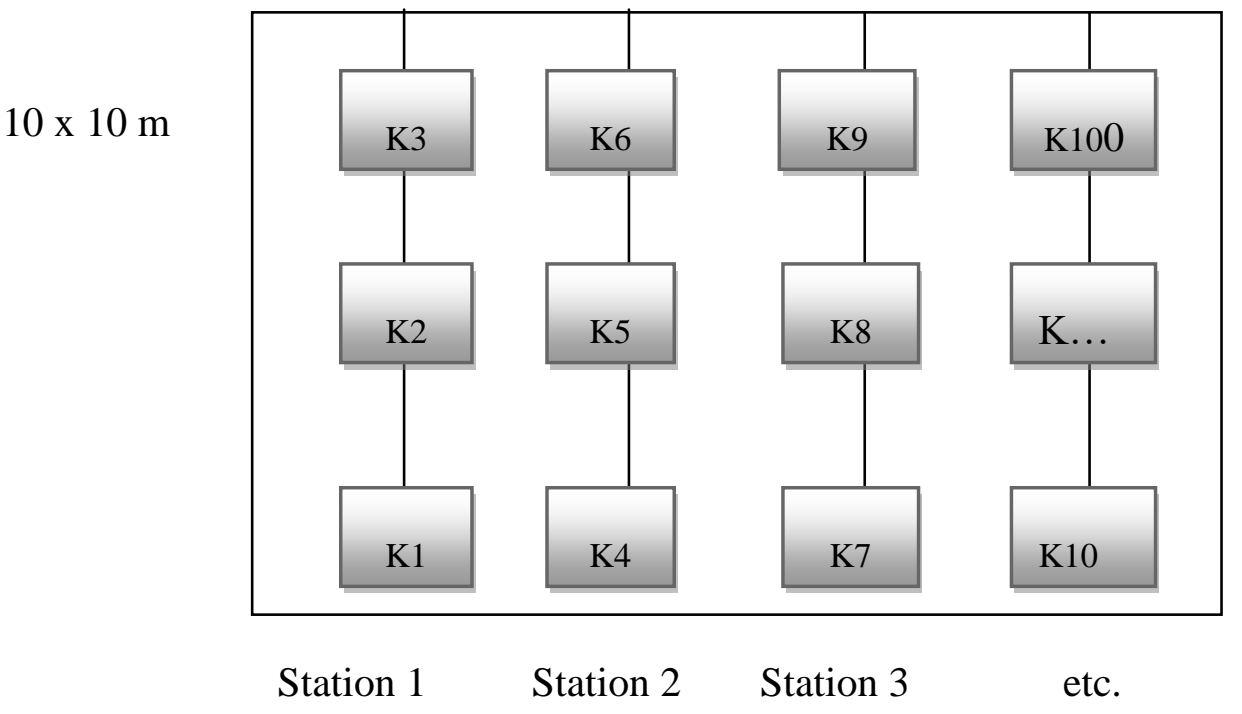

Picture 2. Map of Field Quadratic Installations 
The data collection technique of the plant species distribution mapping refers to Soenaryanto (1976) with reference to the field measurement results conducted by systematic sampling. Plant species identification done based on techniques of interview, documentation study and Forestry Services. The data are analyzed descriptively. Population utilization of research result in instructional media use student of Department of Biology Education FMIPA Undiksha, Semester V class A, B, and C. The sample is student class $\mathrm{V}$ class A with number of student counted 25 people. The sampling technique is by using random sampling technique. The method of data collection is interview and observation. The data are analyzed descriptively

\section{RESEARCH RESULTS AND DISCUSSIONS}

Research Results

The Distribution Map of the Plant Species

The distribution map of plant species can be seen in details on Picture 4.4. Based on their distributions, species of Dysoxylum sp distribute most dominant as many as 137 individual species. Species of Lansium sp distribute as many as 39 individual species, Elmerillia ovalis as many as 28 individual species. Furthermore the others in the area are Amomum sp, Mimusops sp, Mimusops elengi, Hopea celebica, Lannea coromandelica, Aegle marmelos, Polyalthia lateriflora, Lithocarpus celebicus, Antidesma bonius, Dracontomelon sp, Michelia alba, Syzygium polyanthum, Elaeocarpus ganitrus, Syzygium cumini, Sarcotheca celebica, Knema laurina, Gironniera subaequalis, Baccaurea racemosa, Ficus rasemosa, Dysoxylum densiflorum, Gnetum gnemon, Garcinia dulcis, Artocarpus heterophyllus, Manilkara sp, Myristica sp, Artocarpus sp, Heritiera littoralis, Garcinia cerlebica, Artocarpus elastica, Cynometra ramiflora, Ficusbenjamina. From those 34 species which belong to 21 families with the amount of individual species as many as 362, have wide, medium, and narrow distribution or only on certain places.

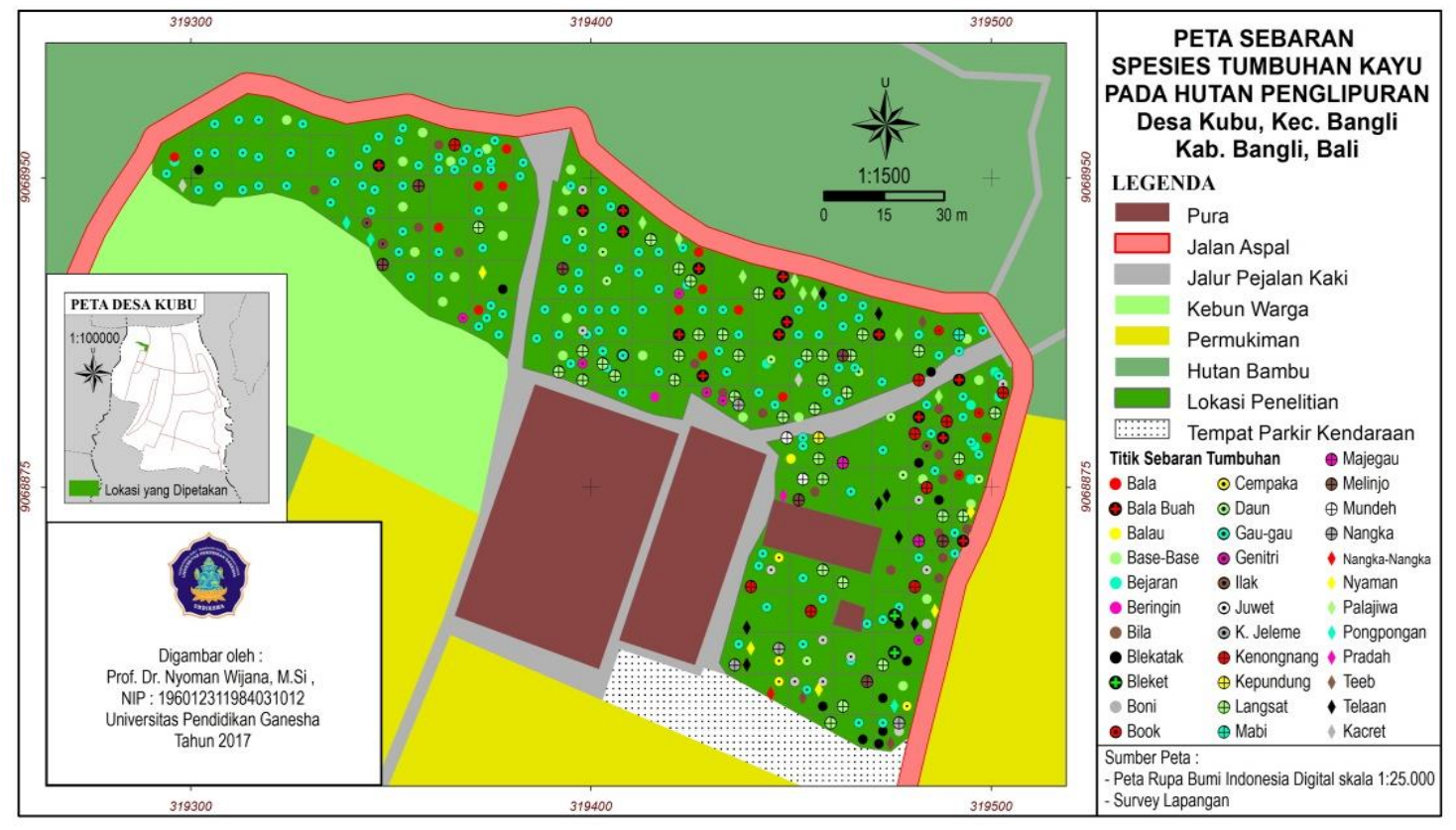

Picture 3 The Distribution Map of Plant Species in the Village Forest of Penglipuran, Bangli, Bali

The Density of Plant Species

The results of the research on species composition in the field include data collection on the total number of individual plant species in the village forest of Penglipuran in each study area quadratic. The recap of plant species in the village forest of Penglipuran is presented in details in the floristic list as shown on Table 1. 
Table 1. Floristic List of Plants in the Village Forest of Penglipuran

\begin{tabular}{|c|c|c|c|c|c|c|}
\hline \multirow[b]{2}{*}{ No } & \multirow[b]{2}{*}{ Family } & \multicolumn{2}{|c|}{ Plant Species Name } & \multirow[b]{2}{*}{ Total } & \multirow[b]{2}{*}{ Density } & \multirow[b]{2}{*}{$\begin{array}{l}\text { Relative } \\
\text { Density }\end{array}$} \\
\hline & & $\begin{array}{l}\text { Local / } \\
\text { Indonesian } \\
\text { Name }\end{array}$ & Scientific Name & & & \\
\hline 1 & Zingiberaceae & Ilak & Amomum sp & 3 & 0,00032967 & 0,89 \\
\hline \multirow{3}{*}{2} & \multirow{3}{*}{ Sapotaceae } & Bala & Mimusops sp & 11 & 0,001208791 & 3,26 \\
\hline & & Bala buah & Mimusops elengi & 16 & 0,001758242 & 4,75 \\
\hline & & Nyaman & Manilkara sp & 5 & 0,000549451 & 1,48 \\
\hline 3 & Dipterocarpaceae & Balau & Hopea celebica & 1 & 0,00010989 & 0,30 \\
\hline \multirow{2}{*}{4} & \multirow[t]{2}{*}{ Magnoliaceae } & Base-base & Elmerillia ovalis & 28 & 0,003076923 & 7,73 \\
\hline & & Cempaka & Michelia alba & 4 & 0,00043956 & 1,19 \\
\hline \multirow[t]{2}{*}{5} & \multirow[t]{2}{*}{ Anacardiaceae } & Bejaran & Lannea coromandelica & 5 & 0,000549451 & 1,48 \\
\hline & & Book & Dracontomelon sp & 4 & 0,00043956 & 1,19 \\
\hline 6 & Rutaceae & Bila & Aegle marmelos & 18 & 0,001978022 & 4,97 \\
\hline 7 & Annonaceae & Blekatak & Polyalthia lateriflora & 11 & 0,001208791 & 3,26 \\
\hline 8 & Fagaceae & Bleket & Lithocarpus celebicus & 2 & 0,00021978 & 0,59 \\
\hline 9 & Euphorbiaceae & Boni & Antidesma bonius & 2 & 0,00021978 & 0,59 \\
\hline \multirow{2}{*}{10} & \multirow[t]{2}{*}{ Myrtaceae } & Daun salam & Syzygium polyanthum & 8 & 0,000879121 & 2,37 \\
\hline & & Juwet batu & Syzygium cumini & 9 & 0,000989011 & 2,67 \\
\hline 11 & Elaeocarpaceae & Genitri & Elaeocarpus ganitrus & 5 & 0,000549451 & 1,48 \\
\hline \multirow{3}{*}{12} & \multirow[t]{3}{*}{ Meliaceae } & Langsat & Lansium sp & 39 & 0,004285714 & 11,57 \\
\hline & & Majegau & $\begin{array}{l}\text { Dysoxylum } \\
\text { densiflorum }\end{array}$ & 2 & 0,00021978 & 0,59 \\
\hline & & Gau-gau & Dysoxylum sp & 137 & 0,015054945 & 37,85 \\
\hline 13 & Oxalidaceae & Kacret & Sarcotheca celebica & 1 & 0,00010989 & 0,30 \\
\hline \multirow{2}{*}{14} & \multirow[t]{2}{*}{ Myristicaceae } & Kayu jelema & Knema laurina & 1 & 0,00010989 & 0,30 \\
\hline & & Pala jiwa & Myristica sp & 9 & 0,000989011 & 2,67 \\
\hline 15 & Ulmaceae & Kenongnang & $\begin{array}{l}\text { Gironniera } \\
\text { subaequalis }\end{array}$ & 9 & 0,000989011 & 2,67 \\
\hline 16 & Phyllanthaceae & Kepundung & Baccaurea racemosa & 1 & 0,00010989 & 0,30 \\
\hline \multirow{5}{*}{17} & \multirow{5}{*}{ Moraceae } & Mabi & Ficus rasemosa & 1 & 0,00010989 & 0,30 \\
\hline & & Nangka & $\begin{array}{l}\text { Artocarpus } \\
\text { heterophyllus }\end{array}$ & 5 & 0,000549451 & 1,48 \\
\hline & & Nangka-nangka & Artocarpus sp & 1 & 0,00010989 & 0,30 \\
\hline & & Tehep & Artocarpus elastica & 3 & 0,00032967 & 0,89 \\
\hline & & Beringin & Ficusbenjamina & 1 & 0,00010989 & 0,30 \\
\hline 18 & Gnetaceae & Melinjo & Gnetum gnemon & 6 & 0,000659341 & 1,78 \\
\hline \multirow{2}{*}{19} & \multirow{2}{*}{ Clusiaceae } & Mundeh & Garcinia dulcis & 2 & 0,00021978 & 0,59 \\
\hline & & Pradah & Garcinia cerlebica & 1 & 0,00010989 & 0,30 \\
\hline 20 & Sterculiaceae & Pongpongan & Heritiera littoralis & 3 & 0,00032967 & 0,89 \\
\hline \multirow[t]{2}{*}{21} & Leguminosae & Telan & Cynometra ramiflora & 8 & 0,000879121 & 2,37 \\
\hline & & Total & & 362 & 0,03978022 & 100,00 \\
\hline
\end{tabular}

There are 34 plant species found in the village forest of Penglipuran which belong to 21 families with details as follows: Plants from the family of Meliaceae have the highest number as many as 178 individual species. Meanwhile plants from the families of Dipterocarpaceae, Oxalidaceae, Phyllanthaceae have the lowest number as many as 1 individual species. Fagaceae (2 individual species), Euphorbiaceae (2 individual species), Zingiberaceae (3 individual species), Sterculiaceae (3 individual species), 
Clusiaceae (3 individual species), Elaeocarpaceae (5 individual species), Gnetaceae (6 individual species), Leguminosae (8 individual species), Anacardiaceae (9 individual species), Ulmaceae ( 9 individual species), Myristicaceae (10 individual species), Annonaceae (11 individual species), Moraceae(11 individual species), Myrtaceae (17 individual species), Rutaceae (18 individual species), Sapotaceae (32 individual species), Magnoliaceae (32 individual species).

Based on the relative density, found that the species with ten highest densities are (1) Dysoxylum sp from the family of Meliaceae; (2) Dysoxylum densiflorum (family of Meliaceae); (3) Elmerillia ovalis (Family of Magnoliaceae), (4) Aegle marmelos (family of Rutaceae); (5) Mimusops elengi (family of Sapotaceae; (6) Polyalthia lateriflora (family of Annonaceae); (7) Mimusops sp (family of Sapotaceae); (8) Syzygium cumini (family of Myrtaceae); (9) Myristica sp (family of Myristicaceae); and (10) Gironniera subaequalis (family of Ulmaceae).

Thus, it can be said that the most "visible" plant species seen as the most dominating species in the village forest of Penglipuran is plant species of Dysoxylum sp and the other co-dominant plants follow.

\section{Instructional Media}

Student of Biology Education Department FMIPA Undiksha, invited to field work practice divided into 5 groups, with task (1) taking data by using quadratic method, (2) identifying plant species that exist in quadrat, (3) counting the number of individual plant species, and use the formula to find relative density and density. The result of observation and interview with the students in terms of utilization of this research result in practical work showed that (1) the installation of squares in the field, overall student $(100 \%)$ showed the right result, (2) Identified plant species there were 32 species from 34 (94.12\%), (3) the students demonstrate good skills in calculating the number of individual plant species present in each square, grouping into mature, sapling, and seedling groups, (4) Calculating the density and relative density already showing correct result. Interviews that have been done with the students show that the students are very helpful in field work practice with first given explanation and orientation of field work location. Images and descriptions of plant species are helpful in the identification of species in the field.

\section{Plant Species Description}

Based on the ten highest density plants, below are the descriptions of those ten plant species.

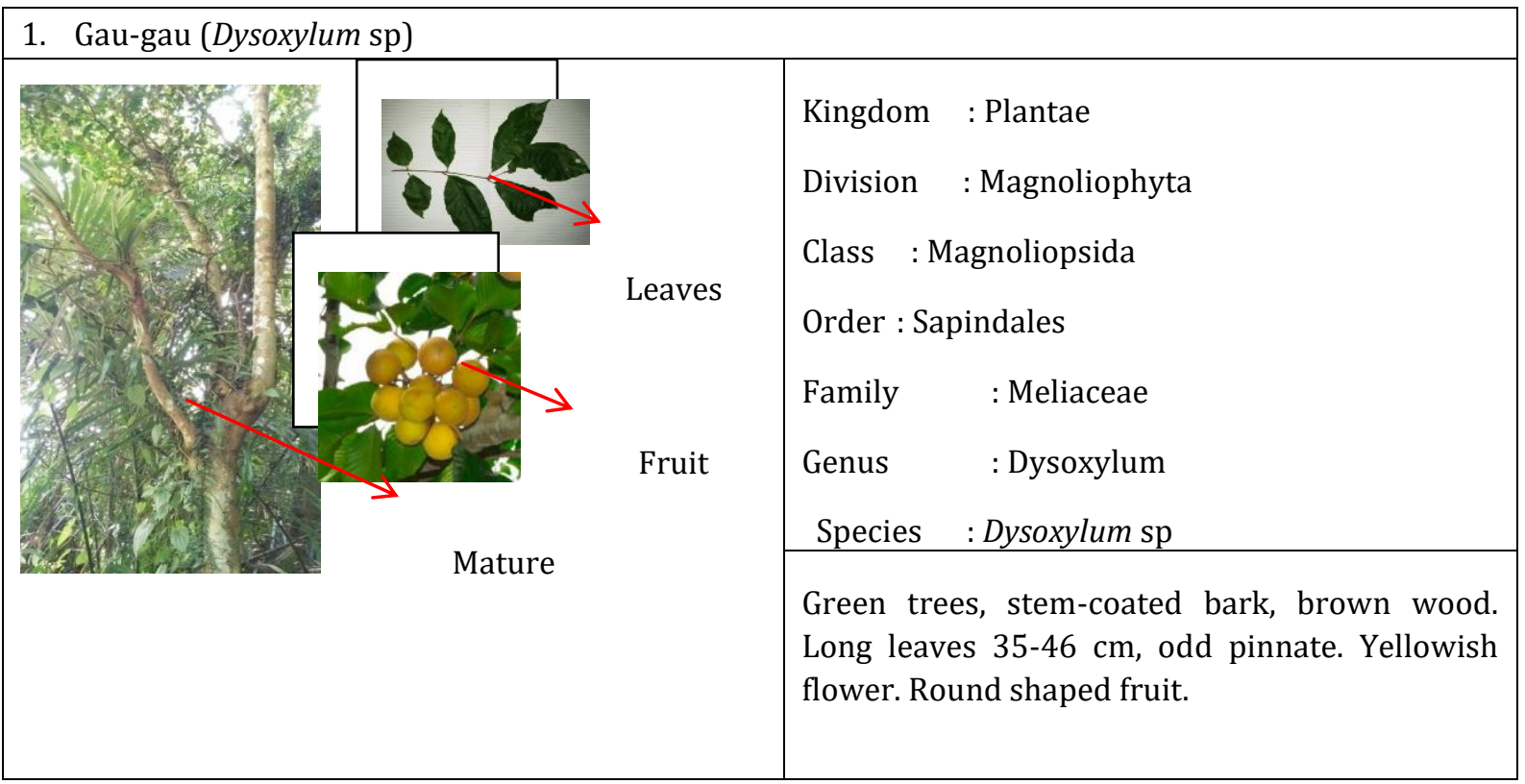




\begin{tabular}{|l|l|}
\hline 2. Majegau (Dysoxylum densiflorum) & $\begin{array}{l}\text { Kingdom : Plantae } \\
\text { Division : Magnoliophyta } \\
\text { Class : Magnoliopsida } \\
\text { Order : Sapindales } \\
\text { Family : Meliaceae } \\
\text { Genus : Dysoxylum }\end{array}$ \\
Species : Dysoxylum densiflorum
\end{tabular}

\begin{tabular}{|l|l|}
\hline 3. Base-Base (Elmerillia ovalis) & $\begin{array}{l}\text { Kingdom : Plantae } \\
\text { Division : Magnoliphyta } \\
\text { Class : Magnoliopsida } \\
\text { Order : Magnoliales } \\
\text { Family : Magnoliaceae } \\
\text { Genus : Elmerillia } \\
\text { Species : Elmerillia ovalis }\end{array}$ \\
\hline Mature & $\begin{array}{l}\text { Plants with height of 45 m. Straight and round } \\
\text { trunk. Sometimes the bottom is big with small top, } \\
\text { lots of branches and twigs. The outer bark is } \\
\text { brownish. Thrust leaves, length 30 cm, width 7-15 } \\
\text { cm, slightly pointed tips. }\end{array}$ \\
\hline
\end{tabular}




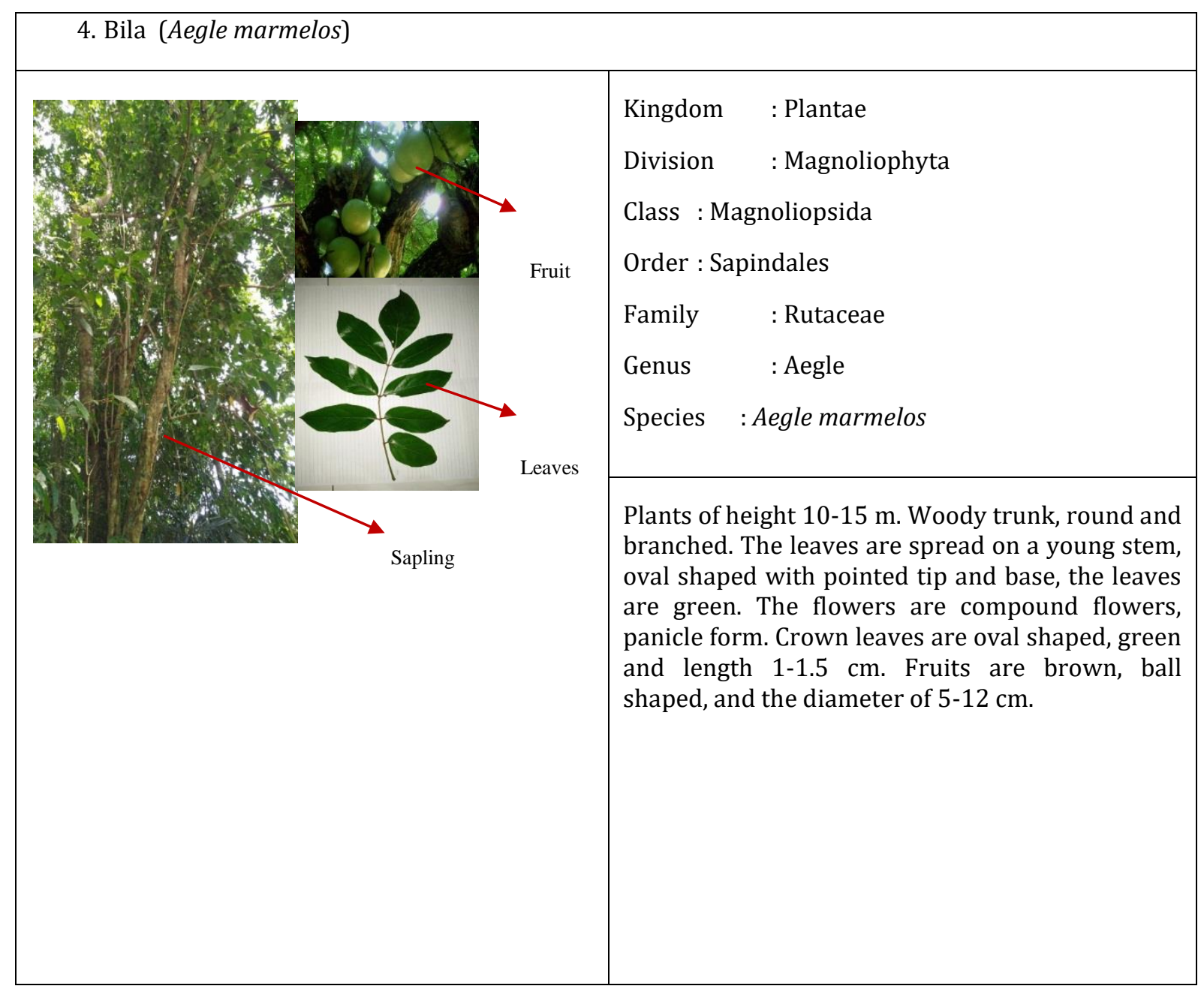

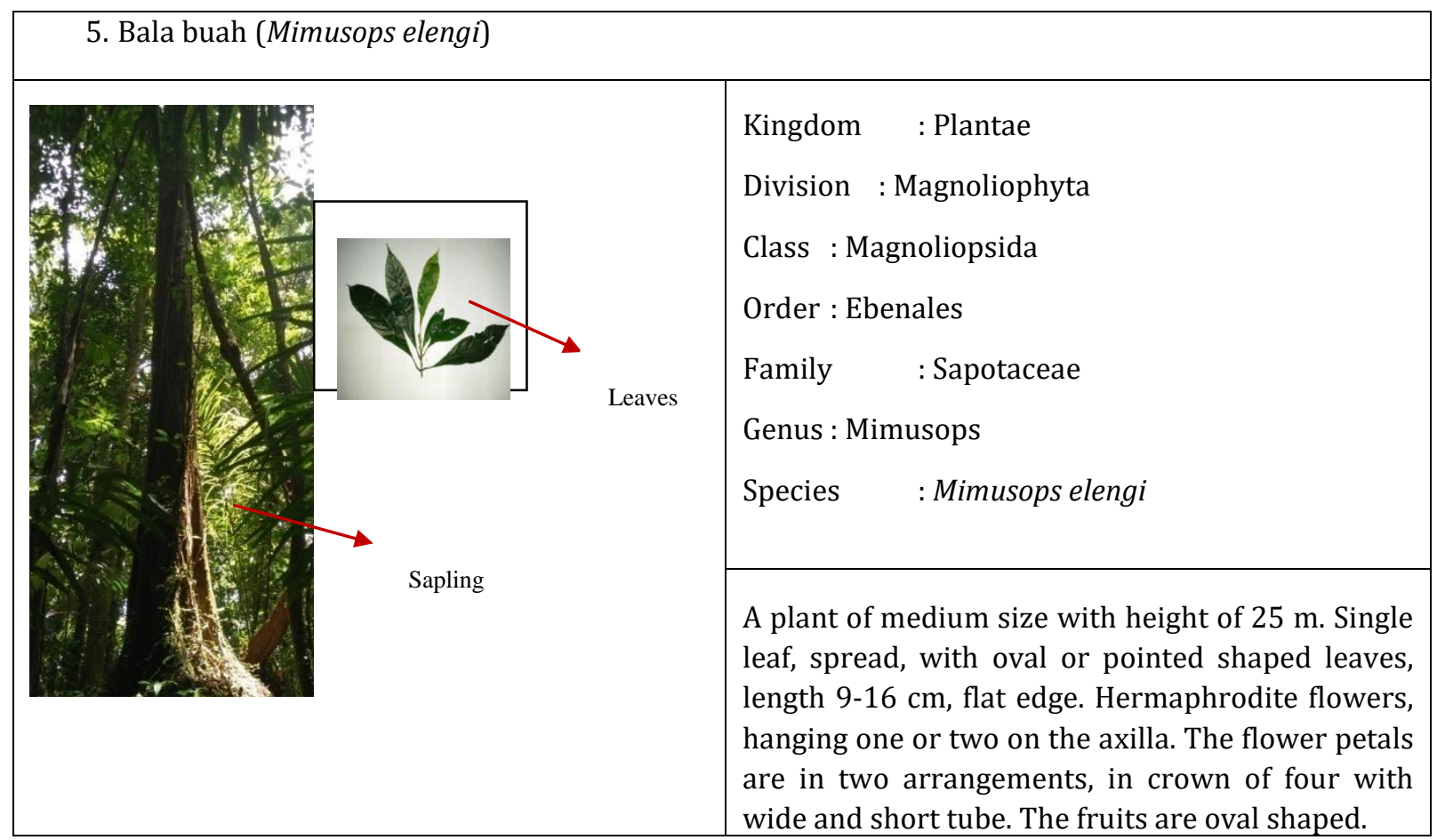




\begin{tabular}{|l|l|}
\hline 6. Blekatak (Polyalthia lateriflora) & $\begin{array}{l}\text { Kingdom : Plantae } \\
\text { Division : Magnoliophyta } \\
\text { Class: Magnoliopsida } \\
\text { Order : Magnoliales } \\
\text { Family : Annonaceae } \\
\text { Genus : Polyalthia } \\
\text { Species : Polyalthia lateriflora }\end{array}$ \\
\hline Leaves & $\begin{array}{l}\text { Plants with height of 5-8 m. Firm and dark } \\
\text { brown trunk with rough texture. Long lancet } \\
\text { shaped leaves with pinnate leaf bones. Small, } \\
\text { yellow greenish flowers. }\end{array}$ \\
\hline
\end{tabular}

\begin{tabular}{|l|l|}
\hline 7. Bala (Mimusops sp) & $\begin{array}{l}\text { Kingdom : Plantae } \\
\text { Divisi : Magnoliophyta } \\
\text { Kelas : Magnoliopsida } \\
\text { Ordo : Ebenales }\end{array}$ \\
Famili : Sapotaceae \\
Genus : Mimusops \\
Spesies $:$ Mimusops sp
\end{tabular}




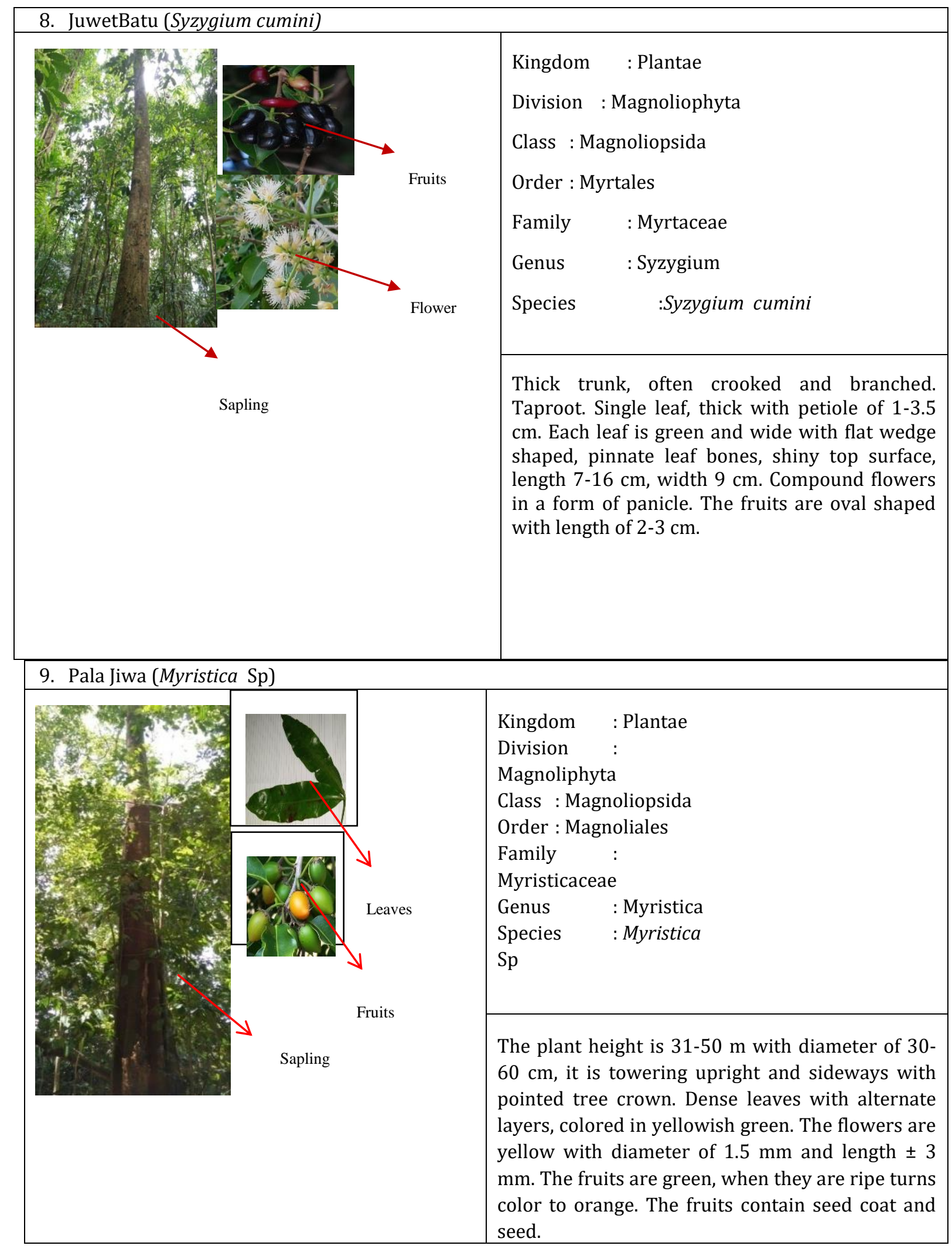




\begin{tabular}{|l|l|}
\hline 10. Kenongnang (Gironniera subaequalis) & $\begin{array}{l}\text { Kingdom : Plantae } \\
\text { Division : Magnoliophyta } \\
\text { Class : Magnoliopsida } \\
\text { Order : Rosales } \\
\text { Family : Ulmaceae } \\
\text { Genus : Gironniera } \\
\text { Species : Gironniera subaequalis }\end{array}$ \\
\hline Sapling & $\begin{array}{l}\text { The height is } 5 \text { m. Single leaf with alternate layers } \\
\text { in shape of oval, pinnate leaf bones, flat edge and } \\
\text { pointed tip. }\end{array}$ \\
\hline
\end{tabular}

\section{Discussion}

Based on the explanation above, it shows that the distribution of rare plant species is influenced by 2 main factors; they are environmental factor (external) and the plants reproduction ability (internal). This is also stated by Polunin (1990) that the limit of plants distribution is influenced by external factor which is the habitat of the plant environment and internal factor which is the reproduction ability.

The environmental light factor, as explained by Polunin (1990) that light is an essential factor for photosynthesis that can ultimately affect the growth of the plants. The plant species that have wide or dominant distribution in all areas of the village forest of Penglipuran are the plant species that have a growth condition with light intensity of 98-965 lux meter. This is in accordance with the conditions in the forest area which have light intensity range of 98-970 lux meter. Meanwhile the plant species that has narrow distribution or only in certain area need a growth condition with light intensity of 120-980 lux meter, this becomes one of the factors that some plant species are unable to grow properly in some parts of the forest.

The plants tolerant nature to the shade will greatly affect their distribution. The plant species with shade tolerant nature will grow more in an area especially in the village forest of Penglipuran that tends to have high plant vegetation so the lights going through the forest will be reduced or blocked. The climatic factor of environmental temperature, as described by Deshmukh (1992), Barbour et al (1987); Mueller-Dombois \& Ellenberg (1974) that the temperature in an environment is a vital influence to a vegetation growth and development, as the temperature determines the speed of chemical reactions and activities including the plants life. The nature of plants which have a wide temperature range will also have a high adaptation nature to the environment. The environment temperature in the village forest of Penglipuran is homogenous on average in each area that is between the ranges of $24-28^{\circ} \mathrm{C}$. The plant species which distribution is wide or almost on the entire forest area have an optimal temperature average on $28^{\circ} \mathrm{C}$. Meanwhile the rare plant species which distribution is on certain areas have optimal temperature average on $24^{\circ} \mathrm{C}$ and $31^{\circ} \mathrm{C}$.

Humidity climatic factor is the amount of water content in the air, as explained by Polunin (1990), Deshmukh (1992), Barbour et al (1987); Mueller-Dombois \& Ellenberg (1974) stating that humidity is closely related to evaporation which is influenced by the climatic temperature, light and wind. Air humidity influences the life of the plants because it directly affects the plants transpiration process. The plant species that have wide distribution in the entire areas of the forest are the ones with average humidity requirement of $76 \%$. This is in accordance with the humidity in the village forest of Penglipuran which is in range of $60 \%-91 \%$. Meanwhile the plant species that exist in certain areas can only grow in areas with certain humidity.

Wind climatic factor, basically the wind affects the ecological factor of water content in the air which implicates the air humidity and environment temperature. According to Polunin (1990) the high speed of the wind can increase the transpiration and decrease the affected cells turgor. However, in every forest area of Penglipuran village, the average of the wind speed is 4-6 MPH. 
Environmental factors from edafic part are factors that depend on the soil condition, either on the texture and physical structure, chemical composition, humidity, temperature, acidity, or even the organisms live in it (Deshmukh, 1992). In general, the soil type in the village forest of Penglipuran is loam soil. According to Kartasapoetra (2004) this kind of soil texture is very good to support the plants growth because loam soil is sticky between its particles, either in dry season or rainy season. Based on that fact, the soil in the village forest of Penglipuran is categorized as fertile soil which can support the plant species growth and development.

In this study, the measured soil component is only the soil acidity. According to Kartasapoetra (2004) soil acidity has great influence to the soil component condition, whether the soil is good or bad to support the plants growth and development, and also it is described in general that plants need optimum $\mathrm{pH}$ of range 5.0-8.0 to run their life activities. Utomo (2015) also stated soil pH which is not too acidic and not too alkaline allows all kind of plants to grow well in that area.

The data of soil pH range in the village forest of Penglipuran are in between 6.0-7.0, which is optimum to plants to grow especially the plant species that are categorized into class of magnoliopsida (dicotyledonous). However, the species distribution is also adjusted to each plant's growth requirements because not all plant species are able to adapt the soil condition with the same $\mathrm{pH}$ content, this can be seen on the less or more species composition in each forest area (Kartasapoetra, 1985).

Human intervention as one of factors that influence the plant species distribution such as The Penglipuran village community's activity that utilize some plant species as medicine and religious ceremony facility (Hindu), also deforestation activity. Plant species that is utilized as medicine is Dysoxylum caulostachyum for diabetes. The plant species that is used as religious facility is Dysoxylum densiflorum.

Plant reproduction ability factor (internal) also becomes one of main factors related to species distribution. Reproduction is the plants ability to multiply themselves. All plant species are categorized as seed plants (spermatophyta) especially closed-seed plants (angiospermae). According to Indriyanto (2006) angiospermae are plants with genuine flower and seed inside the ovary which has many shapes, but mostly round. The distribution of species categorized as angiospermae can be spread by birds, insects, wind, human, etc. Therefore those plant species has wide distribution. However, there are plant species that are distributed on certain area.

Biology Learning, especially Plant Ecology is in need of instructional media, especially in its study of forest ecosystem. Forest ecosystem is a very complex ecosystem. The complexity occurs because of the high plant density, the diverse plant species, and the varied climatic and edaphic factors. By using the results of this study as a reference, the students are very helpful in carrying out their fieldwork practice. This is in line with the opinion expressed by Sugiyanto (2000) which states that the use of instructional media aims to clarify information or instructional messages, emphasize important sections, give variations in teaching, clarify the structure of teaching and motivate learning. Thus it can be said that the learning media is to have a clear function is to clarify, facilitate students understand the concept / theory, and create a message curriculum that will be delivered to students to be more interesting, so that student learning motivation increases and learning process can be more effective and efficient

\section{CONCLUSIONS AND RECOMMENDATIONS}

Based on this study results, there are some conclusions, they are: (1) There are 34 plant species, categorized into 21 families with 362 individual species, found in the village forest of Penglipuran, Subdistrict of Kubu, Regency of Bangli, Bali, Indonesia. The mapping distribution of these 34 species known that they have wide, medium, and narrow distribution; and (2) There are ten plant species that have high relative density, they are (a) Dysoxylum sp from family of Meliaceae; (b) Dysoxylum densiflorum (family of Meliaceae); (c) Elmerillia ovalis (Family of Magnoliaceae), (d) Aegle marmelos (family of Rutaceae); (e) Mimusops elengi (family of Sapotaceae; (f) Polyalthia lateriflora (family of Annonaceae); (g) Mimusops sp (family of Sapotaceae); (h) Syzygium cumini (family of Myrtaceae); (i) Myristica sp (family of Myristicaceae); and (j) Gironniera subaequalis (family of Ulmaceae). The results of this study can be used as a media in learning Biology, especially in Plant Ecology.

Based on the conclusions above, here are some recommendations (1) By this mapping of plant species distribution in their natural environment, then the community can do in-site conservations; and (2) Based on plant species types found in the field which have been mapped, then a new destination can be developed in the forest ecosystem. 


\section{REFERENCES}

Barbour, M. G; J. H. Burk and W. D. Pitts. 1987. Terrestrial Plant Ecology. Inc. California : The Benjamin/ cummings Publishing Company.

Deshmukh, I. 1992. Ekologi dan Biologi Tropika, Terjemahan R.E. Soeriaatmadja. Jakarta: Yayasan Obor Indonesia.

Indriyanto. 2006. Ekologi Hutan. Jakarta: Bumi Aksara.

Kartasapoetra A. G. 2004. Klimatologi: Pengaruh Iklim Terhadap Tanah dan Tanaman. Jakarta: Bumi Aksara.

Kartasapoetra, G, dkk. 1985. Teknologi Konservasi Tanah \& Air. Jakarta : PT Adi Mahasatya.

Mueller-Dombois, D., H. Ellenberg. 1974. Aims and Methods of Vegetation Ecology. Sanfransisco : W. H. Freeman and Company.

Polunin, N. 1990. PengantarGeografi Tumbuhan dan Beberapa Ilmu Serumpun, Terjemahan Gembong Tjitrosoepomo. Yogyakarta: Gajah Mada University Press.

Sugiyanto. 2000. Perkembangan dan Belajar Motorik. Jakarta : Universitas Terbuka.

Utomo, M, dkk. 2015. Ilmu Tanah. Jakarta: Pranadamedia Group.

Wijana, Nyoman. 2014. Metode Analisis Vegetasi. Yogyakarta: Graha Ilmu. 